\title{
Sobre ser enfermeiro e sobre o futuro da Enfermagem
}

Tenho refletido bastante nos últimos anos sobre o significado de ser enfermeira e de fazer enfermagem e me parece claro que o olhar do enfermeiro é o do profissional de Saúde e não da doença. Isso significa que olho para o indivíduo/família/comunidade que será objeto de cuidado e enxergo este indivíduo/família/comunidade como um todo psicossóciocultural e espiritual, além do biológico. Procuro compreender este indivíduo, suas aspirações, como se adapta ou não a condições internas e de seu ambiente e como posso ser facilitadora nestas dimensões para que sua adaptação alcance o melhor potencial de saúde e auto-cuidado possíveis. Porém, ainda constato pessoas que levam consigo o título de bacharéis em enfermagem e carregam em seu olhar o profissional da doença, que limita o ser/família/comunidade à sua frente a uma queixa ou a um órgão específico e que consideram as dimensões psicossócioculturais-espirituais "enrolação" e parte absolutamente secundária a ser tratada. Esta forma de pensar - creiam-me - é diametralmente oposta ao sentido filosófico da Enfermagem desde seus primórdios e que faz desta uma profissão essencial ao futuro da humanidade.

A NANDA (North American Nursing Diagnosis Association) 2012-2014 descreve treze (13) domínios de atuação diagnóstica do enfermeiro em seu fazer. Desses treze, onze (11) incluem a esfera ligada à saúde mental e psico-sócioespiritual do indivíduo/família/comunidade enquanto que apenas dois (2) são da esfera biológica. E aí me pergunto: por que é que ainda há enfermeiros que insistem em dizer que os aspectos psicossócioespirituais e culturais são "menores", "balela”, “complementares”, etc.?

Parece claro que a NANDA nos coloca que não. É melhor cair a ficha. Para a esfera biológica, adequase o modelo biomédico (que é excelente para a Medicina). Mais que isso, não há necessidade de haver massa pensante na enfermagem se somente a esfera biológica for considerada. O profissional operacional (auxiliar e técnico) é suficiente para prover cuidados gerais nesta esfera e de forma exata e competente. Porém, quantas feridas não se fecham ou se infectam apesar das fantásticas coberturas que o mercado biomédico oferece? E por que será? Na maioria das vezes porque a ferida não é o foco. Por trás dela há um ser humano que poderá estar sofrendo emocionalmente, socialmente, espiritualmente e sua descrença, frustração e isolamento social causam queda da resistência imunológica a agressões físicas.

Por melhor que seja a cobertura, sem injetar fé e esperança ou, por vezes, apenas ouvir este indivíduo, não serão encontrados os verdadeiros e melhores caminhos na recuperação desta pessoa. Não é à toa que se oferece preparo intensivo durante o curso de graduação em enfermagem com disciplinas de comunicação, psicologia, bioética e antropologia. Estas são ferramentas essenciais para alcançar o centro de cura do ser humano, que é sua alma. Agora afirmo: esta é área de competência do Enfermeiro e não de seu pessoal operacional. Não haverá no futuro, lugar para enfermeiros limitados e presos ao modelo biomédico.

Prefiro, como enfermeira e profissional liberal que sou, ser livre para conhecer muito bem minha clientela, pensar sobre ela, diagnosticar suas necessidades, prever os resultados de meu fazer e de minha equipe, agir ou intervir e avaliar o processo e como o indivíduo respondeu interna e externamente à minha atuação/intervenção, melhorando sua qualidade de vida total, integrada e não facetada. Este indivíduo necessita voltar à sociedade seguro, com o potencial para o auto-cuidado motivado e participante de seu processo de saúde. 
Talvez eu esteja ficando velha, sei lá. Afinal, são trinta e tantos anos de profissão (...) e idosos ficam meio intolerantes e rabugentos com reducionismos e falta de visão, pelo menos no meu caso. Há que se ampliar a visão de mundo, prever as necessidades futuras e resolver os problemas, ao invés de ficarmos nos lamentando sobre eles. A Enfermagem do futuro é assim: rica, com boa auto-estima (chega de baixa autoestima crônica!), muito, mas MUITO bem preparada e/ou disposta a trabalhar com seres humanos em todas as suas dimensões e coerente com sua linda e orgulhosa história! Leia-se mais sobre Wanda Horta, Martha Rogers, Jean Watson, Florence Nightingale, dentre outras. Essas pessoas não configuravam um bando de malucas que ficavam elocubrando sobre uma enfermagem perfeita, mas sobre a importância direta da ação da Enfermagem e do enfermeiro na prevenção, promoção e recuperação da saúde do indivíduo como um TODO e nunca somente na esfera biológica. Escolheu enfermagem? Faça Enfermagem. Não está feliz? Pois seja! Procure outra área! O universo agradece!

Ana Cristina De Sá ${ }^{1, a}$ 